\title{
Alimentary Expenditure of the Different Socio-Vocational Classes of the Population in Greece (1957-2005): A Description of the Dietary Models
}

\author{
Dr. Ioannis Sotiropoulos \\ Department of Finance and Auditing \\ Technological Educational Institute of Epirus \\ L.Ioanninon 210, 48100 Preveza, Greece \\ E-mail: sotiropoulosioan@yahoo.gr \\ Dr. Georgios Georgakopoulos (Corresponding Author) \\ Amsterdam Business School - Accounting Group \\ University of Amsterdam \\ Roetersstraat 11, Amsterdam 1018WB, the Netherlands \\ E-mail: g.georgakopoulos@uva.nl \\ Dr. Ioannis-Dionysios Salavrakos \\ Department of Agribusiness management \\ University of Ioannina, Agrinio 30100, Greece \\ E-mail: isalavra@cc.uoi.gr
}

\begin{abstract}
The focus of this paper is on food expenditure in Greece from 1957 to 2005 from a socio-vocational perspective. Our main interest lies in the description of the form and development of the basic alimentary models of the different professional layers of the population. This takes place through the examination of Statistical information presented in the Household Budget Surveys published by the National Statistical Service of Greece. We look at food consumption on the grounds of professional criteria (directors vs. workers for example); and of the workers' place in the workforce (employers, employees, unemployed, etc.). By considering the fundamental changes in alimentary patterns in post war Greece we attempt to comprehend the respective dietary behaviours and the ways different professional layers brought about the associated changes over time.
\end{abstract}

JEL Classification: E21, Q11, M31

Keywords: Socio - vocational variables, Consumption, Dietary models

\section{Introduction}

With the exception of one study (Karapostolis 1983) very little mention is made in the academic literature on the effects socio-vocational attributes of the population have on food consumption in post-war Greece. A qualitative description and analysis of the alimentary consumption of the different professional categories take place here. These attempts highlight the similarities, differences, convergence and divergence existing among the socio-vocational classes both in the same time period and over time. In that manner we manage a more complete description of the examined alimentation patterns by stressing existing particularities, the extent and intensity of observed behaviours, and the vocational classes that lead and/or follow the introduction of those alimentary consumption changes. By doing so we set the grounds for understanding the causes that formulated the specific food consumption patterns and their redevelopment over time.

Sources of data for our study were the official annual Household Budget Surveys conducted by the National Statistical Service of Greece (ESYE) over a fifty year period.

\section{Methods}

In the contemporary era food is not a simple product with nutritious value but is represented by "complete packages with specific attributes" (Lancaster 1966, Georgakopoulos and Thomson 2005, Georgakopoulos et al. 2006, Georgakopoulos et al. 2008). In addition food consumption is taking place in a constantly changing socio-economic 
environment (Deaton 1992) in societies with many different classes. In this context knowledge advancement in consumption behaviour can only take place through the application of novel research perceptions and methods.

Behavioural analysis of demographic classes without being unknown to researchers has not been the main focus of scientific investigation. Diversity in behaviours has been identified in socio-economic classes (Karapostolis 1983). However its importance in alimentary consumption changes has not been acknowledged yet. This is due to some classes leading those changes while others follow those or persist with more traditional dietary models of consumption (Sotiropoulos and Mygdakos 2004a, b, 2005, Sotiropoulos et al. 2006).

Analysis usually focuses on description of statistical information provided by Statistical Services without additional data treatment. A relatively new method (Sotiropoulos et al. 2010, Sotiropoulos and Frangos 2009) examines the natural characteristics of alimentary consumption (plant and/or animal-based consumption), the technical features of the production process (agricultural/industrial), biological features and health aspects. The latter parameter is of particular importance since increased animal-based food product consumption appears to have led to increased heart disease incidents. There seems to be an entanglement between natural and biological characteristics of the alimentary models. In this light a more holistic examination of alimentation is in need. A similar relationship seems to exist between technical features and biological aspects of the dietary patterns (e.g. cases of cancer and other health problems - see Sotiropoulos and Demoussis 2002).

The current paper attempts to examine the role different vocational layers of the population have played in changing the alimentary behaviour in Greece over time. Emphasis is given on normal and extreme alimentary behaviours. However, more details on these latter aspects will be given in subsequent work.

Sotiropoulos and Frangos (2009) give the basic qualitative interrelation that was used here to describe the alimentary models:

$\mathrm{CM}_{\mathrm{d}}=\left(\mathrm{Ch}_{\mathrm{n}}, \mathrm{Ch}_{\mathrm{t}}\right)$

where:

$$
\begin{aligned}
& \mathrm{CM}_{\mathrm{d}}=\text { Description of the consumption pattern } \\
& \mathrm{Ch}_{\mathrm{n}}=\text { Natural features } \\
& \mathrm{Ch}_{\mathrm{t}}=\text { Technical features }
\end{aligned}
$$

The above can be rewritten as::

$$
\mathrm{Q}_{\text {alimentary pattern }}=\left(\mathrm{Q}_{\text {natural characteristics, }}, \mathrm{Q}_{\text {technical characteristics}}, \mathrm{Q}_{\text {biological characteristics }}\right)
$$

and further expanded to:

$$
\mathrm{Q}_{\text {alimentary pattern }}=\left(\mathrm{Q}_{\text {plant components }}, \mathrm{Q}_{\text {animal components }}, \mathrm{Q}_{\text {agricultural components }}, \mathrm{Q}_{\text {industrial components }}, \mathrm{Q}_{\text {biological components }}\right)
$$

Our data analysis was based on a statistical description of the data disclosed in the annual Household Budget Surveys over the fifty year reference period with the usage of spreadsheets (see ESYE several years and in specific: 1957/58, 1963/64, 1974, 1981/82, 1987/88, 1993/94, 1998/99, 2004/05).

\section{Alimentary patterns in Greece from 1957 to 2005}

Patterns of alimentary consumption in Greece changed radically in the post-war period. In the 50s alimentation was based on the traditional "Mediterranean" model. Half a century later it can be characterised as "industrial - international - Western origin" (Sotiropoulos and Demoussis 2002).

The main food expenditure in the Mediterranean models of alimentation was on rural, plant-based products and it was taking place within the household (see table 1 and Sotiropoulos et al. 2010). In the industrial category, expenditure is taking place "away from home", on industrial food and animal-based tertiary products (in the 80s and 90s) that incorporate the costs of service provision (trading, marketing, and financing).

Traditional Mediterranean alimentation was grounded on: the triptych "bread - wine - olive oil"; the social dimension of food consumption within the patriarchal household with the participation of friends and relations; and the long and increasing duration of meals in conjunction with public holidays, anniversaries and other social events. Food consumption was based on bread, legumes, sheep and goat meat. The latter also had cultural and/or religious dimensions [1].

In west and north Europe and North America on the other hand alimentation is based on greasier foods of animal origin (beef, fat, milk, beer, whisky, potatoes, etc.). Bread consumption is very limited, wine and olive oil almost non existent, industrial delivery of products and food processing are very important. Other features refer to intense agricultural inputs and fast-food mentalities to a smaller extent. 
These are two completely different civilisations with particular cultural symbols and values. In table 1 a synopsis of the development of the alimentary models in Greece can be seen from 1957 to 2005; from the Mediterranean tradition of the $50 \mathrm{~s}$, to the industrial consumption of animal based food in the 70s and $80 \mathrm{~s}$, to the contemporary post industrial era of food consumption away from home (Sotiropoulos et al. 2010).

\section{Alimentary Consumption of the Different Vocational Layers of the Population.}

\subsection{Alimentary Consumption of the Higher Vocational Layers.}

In the 1950s higher vocational classes (directors, employers) of the population in Greece had already started to adopt "western - international" dietary behaviours. This when the majority of the Greek society was adhering to the Mediterranean alimentation model (see tables 4.1.1 and 4.1.2). There was an increased consumption in industrial (processed) food products, meat and expenditure away from home. On the other hand cereal and other rural products' consumption was decreasing.

From the 70s onwards the rest of the Greek society follows these trends. Cereal consumption gradually decreases but at slightly lower rates than those of the higher vocational layers.

In meat consumption higher vocational layers lead the new behaviours. The rest of the population follows this increased consumption trend (till the $80 \mathrm{~s}$ ) and the subsequent decrease with a small time lag.

A similar observation with a stronger trend was made for the category of food expenditure away from home. There is a rapid convergence of behaviours. However fluctuations are observed throughout the reference period. Past the mid $90 \mathrm{~s}$ there is an even greater expenditure on alimentation away from home from the higher vocational layers in relation to the mean position of the population.

Differences in behaviours were also observed within the higher vocational layer category. Specifically employers: a) have a greater expenditure on alimentation away from home than directors do in the $70 \mathrm{~s}$, even though this was much smaller in the Mediterranean model; b) expenditure on cereals was and remained at higher levels; c) meat consumption increased initially and then decreased in the $90 \mathrm{~s}$.

All other food expenditure categories for higher income earners follow the mean position of the population. However there are some worth noticing differences. Similarities refer to a gradual decrease of expenditure on vegetable, fruit, fish, oils, and sugar-based products over time. The only exception is that of non-alcoholic beverages where consumption increases. Expenditure on fish, dairy, fruits, and sugar-based products was always larger for directors than it was for employers in general. On oils and non-alcoholic beverages it was always greater for employers. The same observation applies for the vegetable food category after the $80 \mathrm{~s}$. Food expenditure for directors is slightly greater than the corresponding one for employers.

By comparing the food consumption of the leading categories with the mean position of the population, conclusions can be drawn for the longer term alimentary trends in dietary behaviour in Greece. Cereals have stabilised at the lowest consumption levels of the examined period with minor fluctuations. These are not that important after the $70 \mathrm{~s}$. In meat consumption the large increases of the 70 s and 80 s were followed by slowly decreasing trends. The same applies at a more intense pace for the fat and oil, and fruit categories. For vegetables, and sugar-based products these falling trends are much smaller. However for the latter category slightly increasing trends were observed in the latest Household Budget Survey. Finally, expenditure on food away from home and on alcoholic beverages has a strong ascending dynamic both for the higher income earning layers and the mean position of the population.

\subsection{Alimentary Consumption of the Lower Vocational Layers.}

An analysis on economic criteria of the alimentary differences existing between different layers of the population (Sotiropoulos et al. 2009) shows that the associated differences not only persist but intensify over time. In contrast, a similar examination on socio-vocational dimensions implies that such alimentary differences start to dull after the 1970s. All vocational classes appear to have similar food consumption behaviours (see tables 4.2.1, 4.2.2, 4.2.3.). They substitute plant-based food with animal-based products, increase consumption of industrial-processed food, increase expenditure on food away from home. Differences are noted on the actual consumed quantities and on the adoption lag existing between the lower and the higher vocational categories.

The adoption lag of the modern food consumption behaviours (animal-based and industrial-processed products, expenditure away from home) has to do with the higher vocational layers initially embracing the new trends. This is gradually followed (after the Household Budget Survey of 1974) by the lower professional classes. Differences on the consumed quantities appear to exist due to the increased levels of spending higher vocational classes have in the associated alimentary categories.

In more detail, cereal consumption for workers was proportionately greater than the mean national position, and much greater than what it was for the higher socio-vocational layers. Workers also follow the general trends on meat consumption. However they consume much less compared to what the higher professional classes do and their position 
is close to the mean national consumption. Workers' expenditure on food away from home is significantly lagging that of directors and employers and it is much smaller than the national mean position but still noteworthy. The consumption trends of the remaining working classes are similar to the mean national position. Fish, dairy, and fruits, are at reduced consumption levels with variations. Oil, vegetable, and sugar-based product consumption is continuously decreasing without any variations. In contrast non-alcoholic beverage spending is continuously increasing at a rapid pace especially in later years.

In summation if compared with the higher professional layers, workers seem to prefer cereal, oil and grease, vegetable and non alcoholic beverage consumption. They significantly lag in expenditure away from home and at a lesser degree in fish, sugar-based product, dairy and fruit spending. They demonstrate a more traditional "Mediterranean" dietary behaviour despite their convergence with the consumption habits of the higher socio-vocational layers. Similar conclusions can be drawn for the remaining lower socio-vocational classes (i.e. unemployed, farmers, employees) with variations on the quantitative characteristics of the associated food consumption. Wage earners for example demonstrate reduced traditional behaviours with increased expenditure in food away from home, sugar-based products, fruits and very little on dairy products.

Conclusions on the alimentary behaviour of the "unemployed or first job seeker" category can only be tentative [2]. However the dietary behaviour of this group can be utilised as the basis for comparisons since the majority of the working force here are unemployed. Proportionate expenditure on food away from home in the unemployed category is much less than what it is for workers. A similar picture appears to exist on expenditure on cereal and oil (with the exception of the Household Budget Surveys for 1988/89 and 2004/05) and non-alcoholic beverages (with the exception of Household Budget Surveys for 1957/58 and 1963/64). On the contrary expenditure for meat, fish, dairy, vegetable, fruit and sugar-based products is greater for this group than what it is for the workers.

\section{Internationalisation, Industrialisation and Alimentary Services}

The examination of dietary consumption of different socio-vocational classes in Greece, using technical criteria of the production process (rural/industrial food products - see Sotiropoulos and Demoussis 2002, and Sotiropoulos et al. 2010), brings forward the industrial/international character of alimentary behaviour (see table 5.1.). This is a constant feature in the conduct of the higher socio-vocational layers of the population and spreads to all other professional categories over time. This feature can be studied through an examination of the consumption structure of animal-based (beef) and international origin products [3].

This industrialisation of the dietary models of consumption is observed in all alimentary categories. For meatstuff this happened for both fresh and processed products [4]. The latter were almost non-existent in the 60s. However their consumption expanded significantly in all socio-vocational groupings over the examined period. At the end of the period relatively lower quantities of processed meat were consumed only by the unemployed. Those who led their introduction initially were the Directors. All other socio-vocational groups started from lower consumption levels but they increased their spending significantly over time at the level of the Directors. In this manner a homogenisation took place in the demand for processed meat products over time.

A similar observation can be made for industrial/processed vegetables. These appeared for the first time in the Greek market after 1969 (with the exception of tomatopaste that was always present at very low levels). The proportionate participation of industrial vegetables in alimentation is even more impressive than the corresponding one for meatstuff. This reaches almost $50 \%$ for cereals (even though the latters' starting point was much higher). Again the higher socio-vocational classes lead this behaviour. However workers also appear to have an increased participation in this diet even though in the beginning of the examined period and in the 60s they were spending more on traditional types of cereals (rural-based such as wheat, maize, flour and rice).

The drastic decrease of legume consumption also denotes the gradual loss of the traditional features of alimentation and their subsequent internationalisation/industrialisation. This can be seen both from the increase of industrial (western origin) food participation in alimentation but also from the adoption of whole food categories of imported products (e.g. bananas after the 1990s). Veal consumption is a typical example of this with a significant proportionate increase in its consumption (led again by the higher socio-vocational classes), whereas expenditure on traditional lamb and kid meat fell drastically.

Spending on alimentation away from home is led by the higher vocational groups and it is followed by the lower classes with relatively smaller proportionate participation [5] (see Household Budget Survey of 1974 and subsequent ones). Of particular interest are the spatial preferences where vocational classes undertake this expenditure (see table 5.2). Lower socio-vocational groups remain attached to traditional cafes (kafenia), whereas higher classes prefer restaurants. The general trend however is for traditional cafes to lose ground. This behaviour is again led by the higher vocational categories and especially the Directors. 


\section{Results}

Two general categories of alimentary behaviour could be formed if vocational criteria are considered. The first would consist (according to definitions from the Household Budget Surveys) of directors, self employed, scientists, private and public sector employees, tradesmen-salespeople, and those occupied in the provision of other services. The second category would include craftsmen, workers, farmers-animal breeders, «non-working people» (such as: occasionally occupied workers; other-revenue earners - landowners for example, and others - see Karapostolis 1983), and unemployed.

The first category is the one that introduces the "modern" dietary behaviours (meat-based consumption, alimentary expenditure away from home, consumption of industrial/processed and international origin food products). The second category is the more "traditional" one that adopts the previous behaviours later and spends relatively smaller amounts on related products and services. In relation to this the more obvious differences in the alimentation of the two categories are on cereal (smaller consumption by the higher vocational classes), meat (greater proportionate participation for the higher classes until the Household Budget Survey of 1981/82, and smaller since), processed food, and expenditure away from home (greater consumption in the higher vocational category). At the same time categorically specific attributes seem to exist among specific classes (these can be vocational-based or not). For example: in the expenditure away from home for self employed and tradesmen-salesmen; in fish and cereal consumption of farmers-animal breeders-fishermen; in the increased consumption in earlier years of sugar-based products for the higher socio-vocational classes and its subsequent decrease; and others. These developments become even more important if existing large differences in total amounts, percentages, and the relative relations between different professions of the population are taken into consideration (see tables 6a,b)

In accordance to Engel's law "increases in disposable income lead to decreases in expenditure on food" (as quoted by Herpin-Verger 2000). This observation applies for all socio-vocational layers in our study. During the 50s major expenditure on alimentation was taking place by the working classes with Directors having the least proportionately. On the other hand in the Household Budget Survey of 2004/05 unemployed groups spend most of their disposable income on food. Directors were again spending the least part. At the general population level expenditure on alimentation has also significantly decreased proportionately. During the 50s the associated costs were half of total expenditure approximately. At the end of the examined period this has decreased to a quarter of the total expenditure with the exception of the directors. The latter's respective costs fell from a quarter of their total expenditure in the 50s to $1 / 5$. A similar picture is drawn for the employer category whose costs fell from $1 / 3$ (in the 50 s) to $1 / 5$ at the end of the examined period (Household Budget Survey of 2004/05).

\section{Conclusions}

The examination of alimentary consumption in post-war Greece using socio-vocational criteria demonstrates the changeable nature of dietary behaviour both: a) over time (1957 - 2995); and b) within the identified vocational layers of the population:

During the first postwar period alimentary models in Greece were characterised by the traditional Mediterranean diet. These were common across the Mediterranean area and especially in Greece with a history of some 5000 years (Renaud 1995). Half a century later they have been completely substituted by the new industrial, western-origin, models with their incorporated service value addition. In the traditional Mediterranean diet food consumption was taking place in the household with plant-based, rural products. In the industrial era alimentation originates from North America and/or Western Europe and it is based on industrial-processed, away from home, meat-based (in the 80s and 90s) and plant-based food (thereafter), but also on value addition through the services of the tertiary sector (trade, finance, advertising).

Since the end of the 50s (in accordance to statistical information provided by ESYE) several economic layers of the population start differentiating their dietary patterns (directors, self-employed professionals, employers and higher income earning layers in general, and younger people - see Sotiropoulos and Demousis, 2002). These are followed relatively quickly by other layers of the population which adopt at a greater or lesser extent and at different rates and priorities the formers' dietary behaviour. These social groups gradually detached from the traditional dietary norms and fully adopted the contemporary trends which in turn they became the models of alimentary consumption for the contemporary Greek society.

The persistent nature of alimentary behaviour is an important reason for a more specialised and in-depth study of the social phenomenon examined here. This research should be extended both in the areas of description and interpretation. The applications of the interrelationships (1), (2) and (3) presented earlier could prove useful towards achieving this goal through the understanding of the causes and mechanisms that bring about change in countries with traditional dietary behaviours such in the case of Greece. 


\section{References}

Deaton A. (1992). “Understanding Consumption”. Clarendon Press. Oxford.

E.S.Y.E. (several years). "Household Budget Surveys (EOP)”. The National Statistical Service of Greece. Athens. Greece.

Georgakopoulos G. and Thomson I. (2005). “Organic Salmon Farming: Risk Perceptions, Decision Heuristics, and the Absence of Environmental Accounting”. Accounting Forum, Vol. 29(1): 49 - 75.

Georgakopoulos G. and Thomson I. (2008). "Social Reporting, Engagements, Controversies and Conflict in an Arena Context”. Accounting Auditing \& Accountability Journal, Vol. 21(8): 1116 - 1143.

Georgakopoulos G., Ciancanelli P., Coulson A., and Kaldis P. (2008). "Stewardship and Risk: an Empirically Grounded Theory of Organic Fish Farming in Scotland”. The Agricultural Economics Review, Vol. 9(2): 16 - 30.

Georgakopoulos G., Thomson I., Coulson A., Sotiropoulos I., and Kaldis P. (2006). "Exploring Social, Financial and Ecological Risks of the Scottish Salmon Industry: an Empirical Evidence for the Business Decision Making to go Organic". The Southeuropean Review of Business Finance and Accounting, Vol. 4(1): 5 - 42.

Herpin N, Verger D. (2000). “La consommation des Français”. Paris. ed. La Découverte.

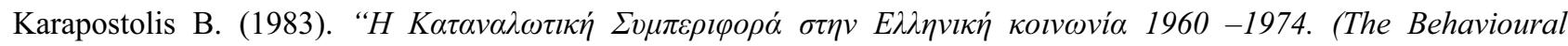
Consumption of Greeks)”. EKKE. A $\theta \dot{v} \alpha$.

Lancaster K. (1966). “A New Approach to Consumer Theory”. Journal of Political Economy, Vol. $74(2)$ : 132 - 157.

Montanari M. (1993). "La Fame e L'Abbondanza. Storia dell' Alimentazione in Europa”, ed. G.Laterza \& Figli, Roma.

Renaud S. (1995). “Le Régime Santé”. Ed. Odile Jacob, Paris.

Sotiropoulos I., Georgakopoulos G., and Kyritsis K. (2010 in press). "Globalisation of the Alimentary Consumption Patterns in Greece (1957 to 2005); an Economic Analysis”. International Journal of Economics and Finance. Vol.2(1).

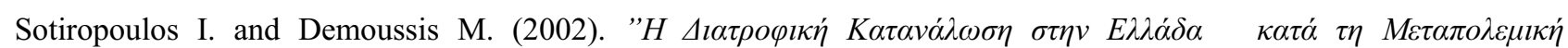

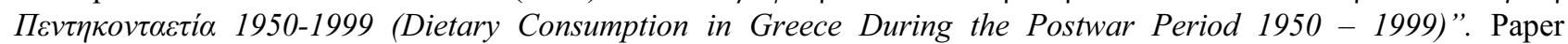
presented in the 7th Panhellenic Conference of E.T.A.G.R.O.

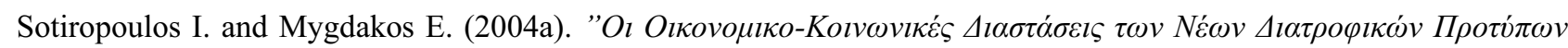

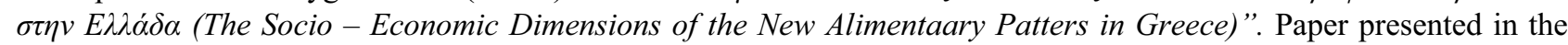
8th Panhellenic Conference of E.T.A.G.R.O.

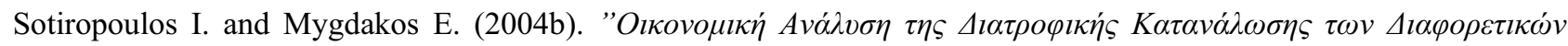

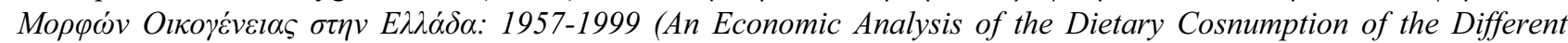
Family Formations in Greece: 1957 - 1999)'”. Paper presented in the 8th Panhellenic Conference of E.T.A.G.R.O.

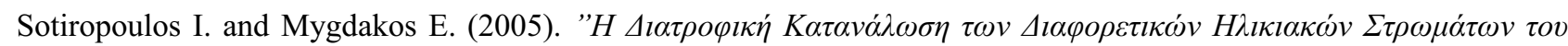

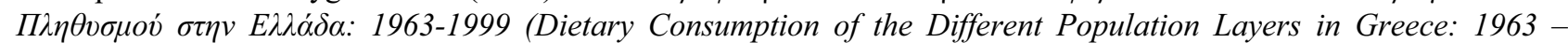
1999)". Paper presented in the 18th Panhellenic Statistical Conference. The Statistical Insitute of Greece (E.S.I.)

Sotiropoulos I., Frangos C. C. (2009). «A new approach to the description of alimentary consumption patterns: The case of Greece». Paper presented in the 2th International Conference. Quantitative and Qualitative Methodologies in the Economic and Administrative Sciences. TEI of Athens.

Sotiropoulos I., Georgakopouls G. and Kyritsis K. (2009)."Globalisation and alimentary consumption: An economic analysis of economic criteria in the case of Greece (1957-2005)'”. Paper presented in the 2th International Conference: Quantitative and Qualitative Methodologies in the Economic and Administrative Sciences. TEI of Athens.

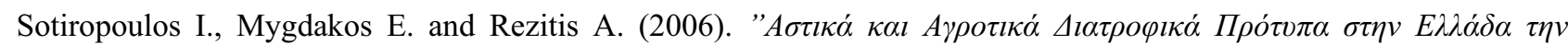

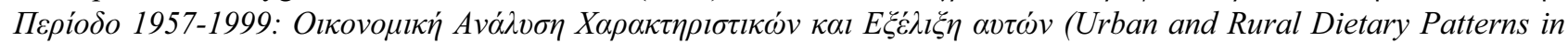
Greece from 1957 to 1999: An Economc Analysis of their Characteristics and Their Evolution)'”. Paper presented in the 19th Panhellenic Statistical Conference. The Statistical Institute of Greece (E.S.I.)

\section{Notes}

Note 1. Sacrifices of sheep to the old gods of the southern Mediterranean cultures; the Holy Communion with wine; biblical references to lamb and kid representing good and bad Christians respectively; the characterisation of ancient Greeks as bread eaters (see for example Montanari 1993).

Note 2. The "unemployed or first job seeker" category also includes part time employees and other rent earners (Karapostolis 1983). 
Note 3. Including animal and/or plant-based products such as: processed meat; homogenised dairy products; imported fruits (e.g. bananas); industrial/processed cereals; processed vegetables and others.

Note 4. Industrialisation here started with the introduction of freezing techniques and general refrigerator usage which was the main driver for the subsequent consumption increase of fresh meat and milk.

Note 5. A similar picture was observed in the 50s $-70 \mathrm{~s}$ with animal-based and processed food.

Table 1. Alimentary Pattern Structure: 1957-2005, (\%).

\begin{tabular}{|c|c|c|c|c|c|c|c|c|c|}
\hline & EOP & '57/58 & '63/64 & 1974 & '81/82 & '87/88 & '93/94 & '98/99 & $04 / 05$ \\
\hline 1 & Cereal & 15.6 & 16.9 & 9.7 & 8.6 & 8.8 & 10.0 & 8.7 & 8.6 \\
\hline 2 & Meat & 16.1 & 14.6 & 25.9 & 26.7 & 23.2 & 20.2 & 15.1 & 14.4 \\
\hline 3 & Fish & 5.3 & 6.5 & 4.5 & 5.0 & 4.7 & 5.0 & 5.1 & 5.4 \\
\hline 4 & Vegetable/Olive Oil & 11.1 & 10.2 & 8.5 & 6.6 & 4.8 & 4.2 & 3.5 & 3.6 \\
\hline 5 & Dairy Products & 12.1 & 8.1 & 11.6 & 11.9 & 12.6 & 13.0 & 12.0 & 12.0 \\
\hline 6 & Vegetables & 10.0 & 8.8 & 9.9 & 8.8 & 8.2 & 8.4 & 8.1 & 7.5 \\
\hline 7 & Fruits & 8.0 & 5.1 & 7.9 & 7.1 & 7.6 & 6.3 & 5.4 & 4.9 \\
\hline 8 & Sugar and pastry making products & 6.4 & 8.3 & 6.8 & 4.8 & 5.3 & 4.7 & 4.0 & 4.2 \\
\hline 9 & Other food categories & 0.9 & 1.1 & 1.3 & 0.6 & 0.9 & 0.9 & 0.6 & 0.9 \\
\hline 10 & $\begin{array}{l}\text { Expenditure on food away from } \\
\text { home }\end{array}$ & 12.3 & 12.8 & 8.9 & 17.4 & 21.1 & 24.4 & 33.7 & 34.7 \\
\hline 11 & Non alcoholic drinks* & 2.1 & 7.6 & 5.0 & 2.3 & 2.8 & 3.0 & 3.7 & 3.7 \\
\hline & Total of Dietary Expenditure & 100 & 100 & 100 & 100 & 100 & 100 & 100 & 100 \\
\hline
\end{tabular}

* Non alcoholic drinks and ice-creams in EOP of 1957/58.

Data Source: ESYE (several years: EOP '57/58, '63/64, '74, '81/82, '87/88, '93/94, '98/99, '04/05).

Table 4.1.1. Alimentary Consumption of the Higher Vocational Classes of the Population (Directors, etc.), 1957 to 2005 , (\%).

\begin{tabular}{|c|c|c|c|c|c|c|c|c|c|}
\hline & EOP & $57 / 58$ & $63 / 64$ & 1974 & $81 / 82$ & '87/88 & '93/94 & '98/99 & '04/05 \\
\hline & Alimentary Categories & 100 & 100 & 100 & 100 & 100 & 100 & 100 & 100 \\
\hline 1 & Cereal & 10.4 & 10.5 & 6.0 & 6.3 & 7.0 & 8.2 & 6.7 & 7.1 \\
\hline 2 & Meat & 18.7 & 12.3 & 26.9 & 24.9 & 20.3 & 19.6 & 13.2 & 13.7 \\
\hline 3 & Fish & 7.1 & 7.5 & 4.4 & 5.3 & 4.2 & 5.2 & 6.6 & 5.0 \\
\hline 4 & Vegetable / Olive Oil & 6.7 & 2.0 & 3.4 & 4.2 & 3.7 & 3.8 & 2.7 & 2.2 \\
\hline 5 & Dairy Products & 12.6 & 10.8 & 12.4 & 12.6 & 11.8 & 12.7 & 11.0 & 10.5 \\
\hline 6 & Vegetables & $19.5 *$ & 4.8 & 8.3 & 6.9 & 7.0 & 6.8 & 6.5 & 6.5 \\
\hline 7 & Fruits & & 4.4 & 9.1 & 8.8 & 7.7 & 6.5 & 5.2 & 4.5 \\
\hline 8 & $\begin{array}{l}\text { Sugar and pastry } \\
\text { making products }\end{array}$ & 4.7 & 8.7 & 7.3 & 6.9 & 5.8 & 4.6 & 3.5 & 4.3 \\
\hline 9 & $\begin{array}{l}\text { Expenditure on food } \\
\text { away from home }\end{array}$ & $20.4^{* *}$ & 37.1 & 19.0 & 21.4 & 29.3 & 29.0 & 40.6 & 41.4 \\
\hline 10 & Non alcoholic drinks & & 1.2 & 1.5 & 1.0 & 1.6 & 1.9 & 2.0 & 3.7 \\
\hline 11 & Other food & & 0.5 & 1.7 & 1.7 & 1.8 & 1.7 & 1.8 & 1.1 \\
\hline
\end{tabular}

Note for tables 4.1.1, 4.1.2, 4.2.1, 4.2.2, 4.2.3.

(*) EOP 1957/58: Fruits are also included in "Vegetables".

(**) EOP 1957/58: Non Alcoholic Drinks and Other food are also included in Expenditure Away From Home.

Data Sourse: ESYE (several years: EOP 1957/58, 1963/64, 1974, 1981/82, 1987/88, 1993/94, 1998/99, 2004/05) 
Table 4.1.2. Alimentary Consumption of the Higher Vocational Classes of the Population (Employers), 1957 to 2005, (\%)

\begin{tabular}{|c|c|c|c|c|c|c|c|c|c|}
\hline & EOP & $' 57 / 58$ & $63 / 64$ & 1974 & '81/82 & '87/88 & '93/94 & '98/99 & '04/05 \\
\hline & $\begin{array}{l}\text { Alimentary } \\
\text { Categories }\end{array}$ & 100 & 100 & 100 & 100 & 100 & 100 & 100 & 100 \\
\hline 1 & Cereal & 12.6 & 12.9 & 7.6 & 7.2 & 6.9 & 7.9 & 7.2 & 7.0 \\
\hline 2 & Meat & 17.9 & 19.9 & 27.4 & 25.5 & 21.5 & 18.6 & 13.2 & 12.2 \\
\hline 3 & Fish & 6.3 & 7.3 & 4.2 & 4.8 & 5.0 & 5.0 & 5.7 & 4.8 \\
\hline 4 & $\begin{array}{l}\text { Vegetable / Olive } \\
\text { Oil }\end{array}$ & 8.0 & 7.7 & 7.2 & 4.4 & 3.4 & 3.1 & 2.8 & 2.4 \\
\hline 5 & Dairy Products & 11.6 & 9.3 & 11.7 & 11.3 & 11.4 & 11.8 & 10.6 & 10.2 \\
\hline 6 & Vegetables & 18.1 & 8.2 & 8.3 & 7.5 & 5.9 & 6.5 & 6.8 & 6.0 \\
\hline 7 & Fruits & & 5.9 & 8.1 & 7.5 & 7.4 & 5.8 & 5.0 & 4.3 \\
\hline 8 & $\begin{array}{l}\text { Sugar and pastry } \\
\text { making products }\end{array}$ & 5.7 & 10.0 & 7.2 & 5.2 & 5.2 & 4.3 & 3.5 & 3.7 \\
\hline 9 & $\begin{array}{l}\text { Expenditure on food } \\
\text { away from home }\end{array}$ & 19.7 & 16.6 & 14.2 & 24.0 & 29.9 & 33.3 & 41.1 & 45.0 \\
\hline 10 & $\begin{array}{l}\text { Non alcoholic } \\
\text { drinks }\end{array}$ & & 1.4 & 1.8 & 0.9 & 1.7 & 2.0 & 2.2 & 3.5 \\
\hline 11 & Other food & & 0.9 & 2.3 & 1.7 & 1.7 & 1.6 & 1.9 & 0.9 \\
\hline
\end{tabular}

Data Sourse: ESYE (several years: EOP 1957/58, 1963/64, 1974, 1981/82, 1987/88, 1993/94, 1998/99, 2004/05)

Table 4.2.1. Alimentary Consumption of the Lower Vocational Layers (Workers), 1957 to 2005, (\%)

\begin{tabular}{|c|c|c|c|c|c|c|c|c|c|}
\hline & EOP & '57/58 & '63/64 & 1974 & $' 81 / 82$ & '87/88 & '93/94 & '98/99 & '04/05 \\
\hline & $\begin{array}{l}\text { Alimentary } \\
\text { Categories }\end{array}$ & 100 & 100 & 100 & 100 & 100 & 100 & 100 & 100 \\
\hline 1 & Cereal & 18.0 & 18.6 & 9.7 & 8.8 & 8.7 & 10.5 & 9.6 & 9.1 \\
\hline 2 & Meat & 14.7 & 15.8 & 25.8 & 27.2 & 24.8 & 22.0 & 15.9 & 14.9 \\
\hline 3 & Fish & 5.1 & 7.1 & 4.0 & 4.3 & 4.1 & 4.4 & 4.2 & 4.6 \\
\hline 4 & $\begin{array}{l}\text { Vegetable / Olive } \\
\text { Oil }\end{array}$ & 11.9 & 9.9 & 9.0 & 6.0 & 4.6 & 4.3 & 3.9 & 3.6 \\
\hline 5 & Dairy Products & 12.3 & 10.4 & 12.4 & 12.5 & 13.0 & 13.4 & 12.5 & 12.3 \\
\hline 6 & Vegetables & $17.8 *$ & 10.0 & 10.4 & 9.2 & 8.3 & 8.4 & 8.2 & 7.5 \\
\hline 7 & Fruits & & 5.7 & 7.9 & 6.9 & 7.2 & 6.0 & 5.1 & 4.6 \\
\hline 8 & $\begin{array}{l}\text { Sugar and pastry } \\
\text { making products }\end{array}$ & 5.9 & 7.6 & 6.4 & 4.8 & 5.3 & 4.7 & 4.1 & 4.1 \\
\hline 9 & $\begin{array}{l}\text { Expenditure on food } \\
\text { away from home }\end{array}$ & $14.3 * *$ & 12.4 & 10.6 & 17.5 & 19.9 & 22.0 & 31.6 & 33.9 \\
\hline 10 & $\begin{array}{l}\text { Non alcoholic } \\
\text { drinks }\end{array}$ & & 1.4 & 1.5 & 0.9 & 1.7 & 2.1 & 2.8 & 4.2 \\
\hline 11 & Other food & & 1.0 & 2.5 & 1.9 & 2.3 & 2.1 & 2.1 & 1.1 \\
\hline
\end{tabular}

$(* * *)$ EOP of $1957 / 58$ and of 1963/64 includes "workers in manufacturing sectors". They do not include "workers in transportation and communication sectors".

Data Source: ESYE (several years: EOP 1957/58, 1963/64, 1974, 1981/82, 1987/88, 1993/94, 1998/99, 2004/05) 
Table 4.2.2. Alimentary Consumption of the Lower Vocational Layers (Unemployed or First Job Seekers****), 1957 to $2005,(\%)$

\begin{tabular}{|c|c|c|c|c|c|c|c|c|c|}
\hline & EOP: & $57 / 58$ & 63/64 & 1974 & $81 / 82$ & '87/88 & '93/94 & '98/99 & $04 / 05$ \\
\hline & $\begin{array}{l}\text { Alimentary } \\
\text { Categories }\end{array}$ & 100 & 100 & 100 & 100 & 100 & 100 & 100 & 100 \\
\hline 1 & Cereal & 14.4 & 18.6 & 9.8 & 9.0 & 9.2 & 10.5 & 9.1 & 9.0 \\
\hline 2 & Meat & 16.2 & 15.7 & 25.6 & 27.5 & 23.1 & 20.2 & 16.5 & 15.3 \\
\hline 3 & Fish & 5.7 & 6.5 & 4.6 & 5.6 & 5.4 & 5.5 & 6.2 & 6.3 \\
\hline 4 & $\begin{array}{l}\text { Vegetable / Olive } \\
\text { Oil }\end{array}$ & 11.8 & 9.4 & 8.6 & 7.1 & 5.7 & 5.7 & 4.7 & 4.5 \\
\hline 5 & Dairy Products & 13.0 & 11.7 & 12.0 & 12.1 & 13.6 & 13.6 & 12.7 & 12.5 \\
\hline 6 & Vegetables & 19.2 & 9.8 & 10.5 & 9.2 & 9.5 & 9.6 & 9.4 & 8.9 \\
\hline 7 & Fruits & & 6.1 & 8.4 & 7.8 & 8.5 & 6.7 & 6.1 & 5.6 \\
\hline 8 & $\begin{array}{l}\text { Sugar and pastry } \\
\text { making products }\end{array}$ & 7.3 & 8.3 & 6.8 & 4.3 & 4.7 & 4.2 & 4.0 & 4.2 \\
\hline 9 & $\begin{array}{l}\text { Expenditure on food } \\
\text { away from home }\end{array}$ & 12.4 & 11.0 & 9.6 & 14.4 & 16.9 & 20.5 & 27.1 & 29.4 \\
\hline 10 & $\begin{array}{l}\text { Non alcoholic } \\
\text { drinks }\end{array}$ & & 1.9 & 1.6 & 0.9 & 1.4 & 1.7 & 2.0 & 3.4 \\
\hline 11 & Other food & & 1.1 & 2.4 & 2.1 & 2.0 & 1.7 & 2.1 & 0.8 \\
\hline
\end{tabular}

$(* * *)$ EOP of 1957/58 and 1963/64 includes "Non professional workers"

Data Source: ESYE (several years: EOP 1957/58, 1963/64, 1974, 1981/82, 1987/88, 1993/94, 1998/99, 2004/05)

Table 4.2.3. Alimentary Consumption of the Lower Vocational Layers (Wage Earners), 1957 to 2005, (\%).

\begin{tabular}{|c|c|c|c|c|c|c|c|c|c|}
\hline & EOP: & $57 / 58$ & $63 / 64$ & 1974 & '81/82 & '87/88 & '93/94 & '98/99 & $04 / 05$ \\
\hline & $\begin{array}{l}\text { Alimentary } \\
\text { Categories }\end{array}$ & 100 & 100 & 100 & 100 & 100 & 100 & 100 & 100 \\
\hline 1 & Cereal & 16.1 & 17.7 & 9.2 & 8.4 & 8.6 & 9.7 & 8.4 & 8.4 \\
\hline 2 & Meat & 15.5 & 14.7 & 25.9 & 26.5 & 23.3 & 20.2 & 14.1 & 14.0 \\
\hline 3 & Fish & 5.0 & 6.4 & 4.1 & 4.5 & 4.2 & 4.4 & 4.4 & 4.7 \\
\hline 4 & $\begin{array}{l}\text { Vegetable / Olive } \\
\text { Oil }\end{array}$ & 11.8 & 10.8 & 8.0 & 6.6 & 4.4 & 3.9 & 3.2 & 3.1 \\
\hline 5 & Dairy Products & 12.7 & 10.5 & 12.4 & 12.9 & 13.3 & 13.4 & 12.1 & 12.3 \\
\hline 6 & Vegetables & 18.1 & 9.2 & 10.1 & 8.9 & 8.1 & 7.7 & 7.2 & 6.8 \\
\hline 7 & Fruits & & 5.8 & 8.2 & 7.3 & 7.8 & 6.2 & 5.1 & 4.6 \\
\hline 8 & $\begin{array}{l}\text { Sugar and pastry } \\
\text { making products }\end{array}$ & 6.4 & 7.9 & 6.7 & 5.2 & 5.5 & 5.1 & 4.2 & 4.3 \\
\hline 9 & $\begin{array}{l}\text { Expenditure on food } \\
\text { away from home }\end{array}$ & 14.5 & 14.6 & 11.1 & 16.8 & 20.7 & 25.1 & 36.7 & 36.6 \\
\hline 10 & $\begin{array}{l}\text { Non alcoholic } \\
\text { drinks }\end{array}$ & & 1.4 & 1.5 & 1.0 & 1.7 & 2.2 & 2.6 & 4.1 \\
\hline 11 & Other food & & 1.0 & 2.8 & 1.9 & 2.3 & 2.1 & 2.0 & 1.0 \\
\hline
\end{tabular}

Data Source: ESYE (several years: EOP 1957/58, 1963/64, 1974, 1981/82, 1987/88, 1993/94, 1998/99, 2004/05) 
Table 5.1. Structure of Basic Product Consumption of the Lower and Higher Vocational Classes, EOP 1963/64 and 2004/05, (\%).

\begin{tabular}{|c|c|c|c|c|c|c|c|c|}
\hline & \multicolumn{2}{|l|}{$\begin{array}{l}\text { Higher } \\
\text { Classes }\end{array}$} & \multicolumn{2}{|l|}{$\begin{array}{l}\text { Lower } \\
\text { Classes }\end{array}$} & \multicolumn{2}{|c|}{$\begin{array}{l}\text { Higher Vocational } \\
\text { Classes }\end{array}$} & \multicolumn{2}{|c|}{$\begin{array}{ll}\text { Lower } & \text { Vocational } \\
\text { Classes } & \\
\end{array}$} \\
\hline & Employers & $\begin{array}{l}\text { Employers } \\
*\end{array}$ & Unemployed & $\begin{array}{l}\text { Non } \\
\text { Workers }\end{array}$ & Directors & $\begin{array}{l}\text { Director } \\
s\end{array}$ & Workers & Workers \\
\hline EOP: & $63 / 64 * *$ & '04/05 & $63 / 64$ & $04 / 05$ & $' 63 / 64$ & $04 / 05$ & $63 / 64$ & $04 / 05$ \\
\hline \multicolumn{9}{|l|}{ Cereal } \\
\hline Bread & 34.5 & 45.9 & 35.5 & 52.4 & 55.5 & 47.6 & 39.2 & 54.8 \\
\hline Flour & 24.2 & 3.5 & 23.8 & 4.7 & 13.8 & 3.5 & 13.1 & 3.3 \\
\hline Processed Cereal & 21.7 & 45.1 & 19.9 & 36.4 & 15.6 & 42.9 & 15.6 & 36.1 \\
\hline Rice & 9.7 & 5.5 & 11.5 & 6.5 & 15.1 & 5.9 & 8.1 & 5.7 \\
\hline other Cereal $* * *$ & 10.0 & & 9.3 & & & & 24.1 & \\
\hline \multicolumn{9}{|l|}{ Meat } \\
\hline Veal & 33.5 & 39.4 & 15.4 & 23.2 & 13.9 & 40.6 & 17.5 & 35.8 \\
\hline Lamb and Kid & 28.2 & 9.5 & 28.8 & 15.0 & 23.4 & 10.6 & 20.7 & 9.8 \\
\hline $\begin{array}{l}\text { Processed Meat } \\
\text { Products }\end{array}$ & 3.0 & 15.0 & 2.1 & 8.6 & 7.2 & 14.3 & 4.3 & 15.0 \\
\hline \multicolumn{9}{|l|}{$\begin{array}{l}\text { Legumes - } \\
\text { Vegetables }\end{array}$} \\
\hline Legumes & 21.5 & 5.1 & 17.1 & 7.4 & 15.3 & 7.9 & 18.8 & 5.7 \\
\hline $\begin{array}{l}\text { Fresh } \\
\text { Vegetables } * * * *\end{array}$ & 56.6 & 76.6 & 62.6 & 61.1 & 72.5 & 52.8 & 59.0 & 55.6 \\
\hline Processed Vegetables & & 14.6 & & 13.2 & & 16.3 & & 15.8 \\
\hline \multicolumn{9}{|l|}{ Fruits } \\
\hline Bananas & & 10.9 & & 9.0 & & 10.6 & & 13.2 \\
\hline \multicolumn{9}{|l|}{ Dairy } \\
\hline Fresh Milk & 18.9 & 26.3 & 16.8 & 24.5 & 20.7 & 27.0 & 18.5 & 28.6 \\
\hline Processed Milk & 15.3 & 7.8 & 12.0 & 7.3 & 26.7 & 7.9 & 17.4 & 9.9 \\
\hline \multicolumn{9}{|l|}{ Oils-Fat } \\
\hline Butter & 2.7 & 4.1 & 1.2 & 3.1 & 12.1 & 4.8 & 3.2 & 3.3 \\
\hline
\end{tabular}

$(*) \quad$ In EOP of 2004/05: «Self employed with hired personnel»

(**) Data from EOP of 1963/64 were used since detailed data per product from the EOP of 1957/58 did not exist for these population categories

$(* * *) \quad$ (Wheat, maize,etc.)

$(* * * *)$ (Including tomato paste) in EOP of 1957/58.

Data Source: ESYE (several years: EOP 1957/58, 1963/64, 1974, 1981/82, 1987/88, 1993/94, 1998/99, 2004/05)

Table 5.2. Structure of Alimentary Expenditure Away From Home in Lower and Higher Socio-Vocational Classes (EOP 1963/64 \& 2004/05 in \%).

\begin{tabular}{|c|c|c|c|c|c|c|c|c|}
\hline & \multicolumn{2}{|c|}{$\begin{array}{l}\text { Higher } \\
\text { Socio-Vocational } \\
\text { Classes }\end{array}$} & \multicolumn{2}{|c|}{$\begin{array}{l}\text { Lower } \\
\text { Socio-Vocational } \\
\text { Classes }\end{array}$} & \multicolumn{2}{|c|}{$\begin{array}{l}\text { Higher Vocational } \\
\text { Classes }\end{array}$} & \multicolumn{2}{|l|}{$\begin{array}{l}\text { Lower } \\
\text { Classes }\end{array}$} \\
\hline & Employers & $\begin{array}{l}\text { Employ } \\
\text { ers* }\end{array}$ & $\begin{array}{l}\text { Unemplo } \\
\text { yed. }\end{array}$ & $\begin{array}{l}\text { Unemploy } \\
\text { ed. }\end{array}$ & Directors & $\begin{array}{l}\text { Director } \\
s\end{array}$ & Workers & Workers \\
\hline EOP: & $63 / 64^{* *}$ & '04/05 & '63/64 & $04 / 05$ & '63/64 & '04/05 & '63/64 & '04/05 \\
\hline $\begin{array}{l}\text { Expenditure } \\
\text { Home }\end{array}$ & & & & & & & & \\
\hline Restaurants & 41.2 & 57.0 & 31.6 & 49.5 & 50.9 & 55.1 & 32.5 & 46.5 \\
\hline Kafenia & 58.8 & 43.0 & 68.4 & 50.5 & 49.1 & 44.9 & 67.5 & 53.5 \\
\hline
\end{tabular}

(*) In EOP of 2004/05 also include «Self employed with hired personnel»

(**) Data from EOP 1963/64 were used since detailed data per product from EOP 1957/58 did not exist for these population categories. 
Data Source: ESYE (several years: EOP 1957/58, 1963/64, 1974, 1981/82, 1987/88, 1993/94, 1998/99, 2004/05)

Table 6a,b. Alimentary Consumption, in Drachmas and Proportionate Relations (\%) per Household Budget Survey: Vocational Criteria.

\begin{tabular}{|c|c|c|c|c|c|c|c|c|c|}
\hline$E O P^{\prime} 57 / 58$ & $I^{*}$ & $I I$ & $I I I$ & $I V$ & V & $V I$ & $V I I$ & VIII & $I X$ \\
\hline $\begin{array}{l}\text { Alimentation (in } \\
\text { Drachmas) }\end{array}$ & 349.9 & 525 & 557.1 & 420.7 & 366.1 & 266.6 & 409.4 & 349.2 & 296.8 \\
\hline $\begin{array}{l}\text { Total Expenditure (in } \\
\text { Drachmas) }\end{array}$ & 861.6 & $1,698.7$ & $2,080.1$ & $1,069.1$ & 932.5 & 656.3 & 868.3 & 859.8 & 750.6 \\
\hline $\begin{array}{l}\text { Alimentation/Expenditure } \\
(\%)\end{array}$ & 40.6 & 30.9 & 26.8 & 39.4 & 39.3 & 40.6 & 47.1 & 40.6 & 39.5 \\
\hline
\end{tabular}

\begin{tabular}{|c|c|c|c|c|c|c|c|c|c|}
\hline$E O P^{\prime} 04 / 05^{* *}$ & $I^{*}$ & II & $I I I$ & $I V$ & $V$ & $V I$ & $V I I$ & VIII & $I X$ \\
\hline Total Expenditure $(€)$ & $1,792.28$ & $2,971.96$ & $3,191.88$ & $2,430.85$ & $2,246.02$ & $1,689.38$ & $1,982.0$ & $3,214.88$ & $1,258.02$ \\
\hline Alimentation $(€)$ & 469.35 & 671.56 & 715.64 & 570.79 & 559.99 & 483.51 & 529.61 & 765.37 & 363.34 \\
\hline $\begin{array}{l}\text { Alimentation/Expenditu } \\
\text { re }(\%)\end{array}$ & 26.2 & 22.6 & 22.4 & 23.5 & 24.9 & 28.6 & 26.7 & 23.8 & 28.9 \\
\hline
\end{tabular}

* I: $\quad$ All households

II: $\quad$ Free lancers, technicians, etc..

III: $\quad$ Directors and Executives

IV: Office employees

V: $\quad$ Salespeople (Categorised as Tradesmen or salesmen after the EOP of 1974)

VI: $\quad$ Farmers,fishermen,etc. (Categorised as farmers, animal-breeders, fishermen, etc. after the EOP of 1974.)

VII: Workers (excluding agriculture) or drivers of public transport

VIII: Self employed 1974)

** No additional vocational categories are mentioned that existed in EOP of $1957 / 58$ with alimentation over total consumption percentage: $54.8 \%$

Data Source: ESYE (several years: EOP 1957/58, 1963/64, 1974, 1981/82, 1987/88, 1993/94, 1998/99, 2004/05) 